\title{
Effect of High Temperature on Fruit Productivity and Seed-Set of Sweet Pepper (Capsicum annuum L.) in the Field Condition
}

\author{
Tran Loc Thuy ${ }^{1}$ and Murakami Kenji ${ }^{2}$ \\ 1. Department of Plant Protection, Cuu Long Delta Rice Research Institute, Can Tho 900000, Vietnam \\ 2. Department of Bioproduction Science, Ishikawa Prefectural University, Ishikawa 921-8836, Japan
}

\begin{abstract}
Chili peppers grow best and are likely to reach the maximum yield at temperature ranging from $21{ }^{\circ} \mathrm{C}$ to $33{ }^{\circ} \mathrm{C}$. In the plastic house, the temperature increases to $42{ }^{\circ} \mathrm{C}$ in the summer. The fruit set and fruit growth were effected correlative with the high temperature condition. In this study, Shishito peppers were grown in plastic house in two periods (in the early stage of April and the end stage of May) in 2012. The difference in temperature between two periods of planting was about $4{ }^{\circ} \mathrm{C}$. In fruit set period of the 2nd planting, the weather condition is disadvantage for fruit growth. During temperature changed in the summer, the fruit weight and the number of seeds per fruit of both "Shishi-homare" and 105c-10 varieties were reduced about 0.5 and 2.8 times in the 2nd planting when compared with the 1st planting. The number of seeds per fruit reduced corresponding with the fruit size under the high temperature condition.
\end{abstract}

Key words: High temperature, seed-set, fruit productivity.

\section{Introduction}

The origin of pepper (Capsicum annuum L.) is Mexico and the neighboring areas of Central America. Shishito is one of four popular sweet pepper cultivars (Hushimi-ama type, Shishito type, Bell type and F1 type) in Japan [1]. Fruit is small, green and non-pungency. In Japan, The crop of sweet pepper begins in the last stage of spring and harvests from May to November [2]. During this time, the temperature increased strongly, when the extreme temperature of more than $40{ }^{\circ} \mathrm{C}$ sometimes was recorded in August [3]. Under plastic house in the field, the inside temperature will be higher. Temperature strongly influenced the development of fruit and flowers of chili pepper [4]. The optimum temperature for chilli pepper cultivation is $21-33{ }^{\circ} \mathrm{C}$. Low and high temperature condition affect the size of fruit and seed germination ability $[5,6]$. Under

Corresponding author: Tran Loc Thuy, Ph.D. student, research field: plant production. changing of weather, temperatures are higher than the optimum chili's growing, thus the plants are objected to disadvantageous temperature period [7, $8]$.

In general, high temperature influences many aspects of plant physiology and growth, which may lead to significant losses in crop productivity in many species due to limited vegetative, reproductive growth and seed yield [9]. According the survey of Erickson and Markhart [10], fruit set and productivity of pepper reduced during periods of high temperature. High temperature frequently occurs after anthesis of chilli pepper and strongly impacts the reproduction and yield. However, the rare investigation about the effect of high temperature on chili pepper crop has been elucidated. Therefore, the present study aimed to study the impact of high temperature during summer period in Japan on the phenological and morphological character of fruits of Shishito pepper. 


\section{Materials and Methods}

The experiment was carried out in plastic house of Okayama University, Japan. Four varieties derived from Shishito (Capsicum annuum L.), viz., "Shishi-homare" (a favorite variety in Japan), "105c-10" (low-pungent mutation line derived from "Shishi-hormare"), "Kounou Shishito" and "Kairyo Shishito" were used in the current experiment.

The seeds were sown in sowing tray in both the planting times. The 1st time was on April 9, 2012 to August 16, 2012, "Shishi-homare" and "105c-10" were planted in this time; and the 2nd time was on May 30, 2012 to October 30, 2012, four varieties were planted and filled with commercial soil (300 mg/L N, $450 \mathrm{mg} / \mathrm{L}$ $\mathrm{P}$ and $370 \mathrm{mg} / \mathrm{L} \mathrm{K}$ ). During the 1st planting, the pots containing the seeds were kept in the growth chamber, which set at a daily 16/8 h (light/dark) with a temperature of $28 / 20^{\circ} \mathrm{C}$, respectively. After three weeks when seedlings were at 3-4 leaf stage, 30 seedlings of each variety were transplanted to plastic pot $(10.5 \mathrm{~cm}$, containing commercial soil) and kept in the plastic house, and distance between two pots is $15 \mathrm{~cm}$. At anthesis stage, 10 plants of each one were transplanted again to the ground in plastic house. The distance between two plants was $50 \mathrm{~cm}$ and the distance between two rows was $1.2 \mathrm{~m}$. The seedlings were trained with two main branches. Depending on the daily temperature, plants were watered once or twice per day. The plants were supplied with fertilizer of NPK fertilize $\left(20 \mathrm{~g} / \mathrm{m}^{2}\right)$, and $\mathrm{Ca}$ and $\mathrm{Mg}\left(80 \mathrm{~g} / \mathrm{m}^{2}\right.$ each), respectively.

Temperature in plastic house was recorded with thermocouples connected to data-logger. The plant growth situation before the 2nd transplanting was recorded. All the individual flowers were labeled for finding the days after flowering (DAF). Fruits from flowers of 28-30 DAF were harvested with one fruit per branch weekly. The morphological characteristic of harvest fruits (fruit size, fruit diameter, fruit length) and number of seeds were recorded. Fruits from labeled flowers were harvested once per week from the last of June to the middle of August for the 1st planting and from middle of August to the end of October for the 2 nd planting. The data obtained were analyzed following Tukey-test $(P \leq 0.05)$.

\section{Results and Discussion}

The temperature in plastic house increased gradually from April 15th, and the highest temperature of $42{ }^{\circ} \mathrm{C}$ was recorded from the early August to the early September (Fig. 1). During the 1 st planting period (Fig. 1a), the temperature averaged from $28{ }^{\circ} \mathrm{C}$ to $33.4{ }^{\circ} \mathrm{C}$ in day and $11.8{ }^{\circ} \mathrm{C}$ to $21.4{ }^{\circ} \mathrm{C}$ at night, which gradually increased and reached a peak of $42{ }^{\circ} \mathrm{C}$ in the early August. The temperature increased nearly $4{ }^{\circ} \mathrm{C}$ from the 1 st planting to the 2 nd planting.

The 1st flower in the 2nd planting appeared in the late July, when the maximum temperature is about 41.6/24.6 ${ }^{\circ} \mathrm{C}$ (day/night) (Fig. 1b). The difference in temperature between the 1 st planting (the early stage of June) and the 2nd planting for the 1st flower opening was $7^{\circ} \mathrm{C}$.

No significant difference was observed between "Shishi-homare" and "105c-10" in the number of days to the 1st flowering. When the temperature increased, the days to the 1st flower reduced, respectively (Table 1). Similar results were reported by Qumer et al. [11]. No significant difference was observed in the node number in all the varieties during both planting times. This might be because all the varieties belong to Shishito group, and thereby exert similar morphological characteristics.

The fruit size of harvested fruits, such as fruit length, fruit weight, fruit diameter and seed number per fruit were recorded in Table 2 and no difference was observed in the fruit weight, fruit length, fruit diameter and seed number per fruit between "Shishi-homare" and "105c-10" in the 1st planting. But when the temperature increased in the 2nd planting, the morphological characteristic of fruits in all varieties changed, fruit weight and number of seeds per fruit of both "Shishi-homare" and "105c-10" were reduced about 0.5 times and 2.8 times, respectively. 


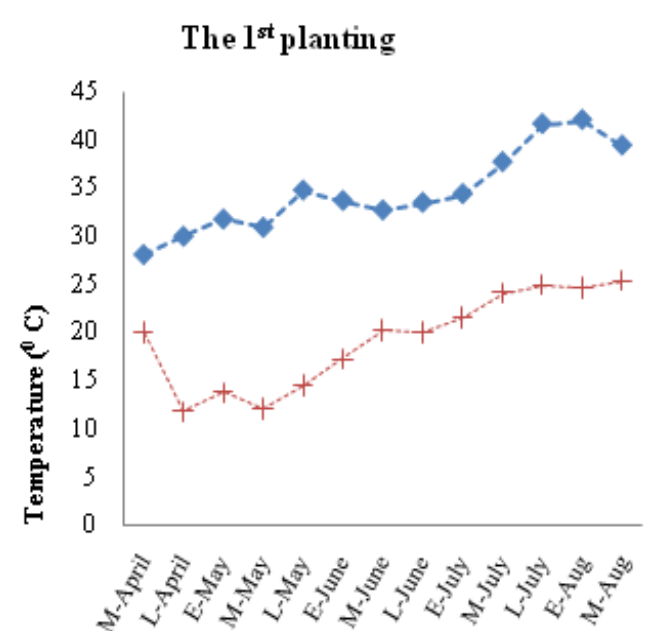

(a)

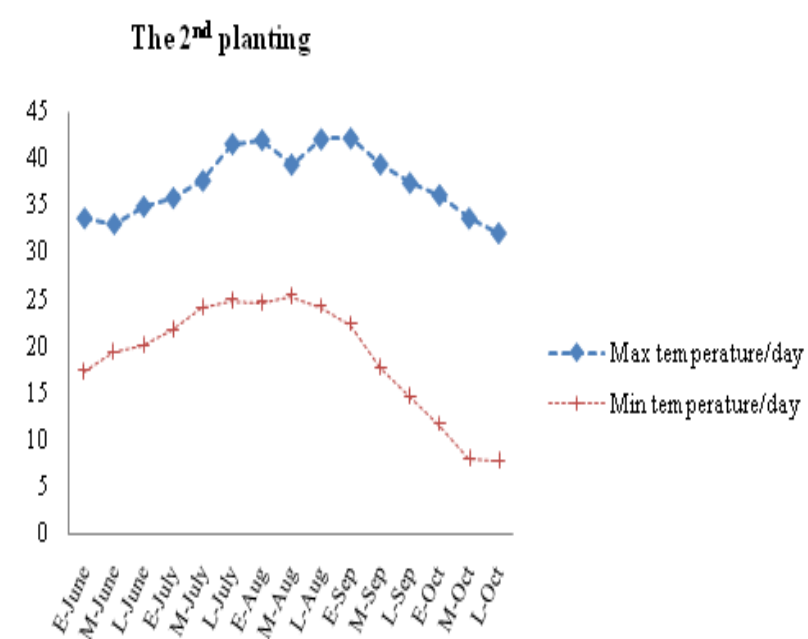

(b)

Fig. 1 The temperature condition during culture of two times planting.

E: the early stage of month (1st-10th), M: the middle stage of month (11th-20th), L: the last stage of month (21st-30th).

Table 1 The number of days to the 1st flowering, the node number of the 1st flower and the plant height in the 2nd transplanting.

\begin{tabular}{lllll}
\hline \multirow{2}{*}{ Plant time } & Variety & $\begin{array}{l}\text { Days to the 1st } \\
\text { flowering }\end{array}$ & $\begin{array}{l}\text { The node number of } \\
\text { the 1st flower }\end{array}$ & $\begin{array}{l}\text { The height in the 2nd } \\
\text { transplanting (cm) }\end{array}$ \\
\hline \multirow{2}{*}{ 1st planting } & Shishi-homare & $57.8 \pm 0.9^{\mathrm{a}}$ & $15.1 \pm 0.7^{\mathrm{b}}$ & $15.4 \pm 0.8^{\mathrm{c}}$ \\
& $105 \mathrm{c}-10$ & $56.6 \pm 0.7^{\mathrm{a}}$ & $14.3 \pm 0.6^{\mathrm{b}}$ & $15.9 \pm 0.62^{\mathrm{c}}$ \\
\hline \multirow{5}{*}{ 2nd planting } & Shishi-homare & $53.4 \pm 1.7^{\mathrm{b}}$ & $15.0 \pm 0.8^{\mathrm{b}}$ & $17.0 \pm 1.0^{\mathrm{c}}$ \\
& 105c-10 & $52.3 \pm 1.1^{\mathrm{b}}$ & $15.1 \pm 0.7^{\mathrm{b}}$ & $18.0 \pm 0.7^{\mathrm{bc}}$ \\
& Kounou Shishito & $53.2 \pm 0.8^{\mathrm{b}}$ & $16.9 \pm 1.0^{\mathrm{a}}$ & $21.8 \pm 1.1^{\mathrm{a}}$ \\
& Kairyo-Shishito & $52.6 \pm 1.3^{\mathrm{b}}$ & $15.1 \pm 1.0^{\mathrm{b}}$ & $19.0 \pm 1.1^{\mathrm{b}}$ \\
\hline
\end{tabular}

${ }^{\mathrm{a}-\mathrm{c}}$ Different letters within the same column indicate a significant difference at $5 \%$ level by Tukey's test.

Table 2 The morphological characteristics of harvested fruits at 28-30 DAA.

\begin{tabular}{clllll}
\hline Plant time & Variety & Fruit weight $(\mathrm{g})$ & Fruit diameter $(\mathrm{cm})$ & Fruit length $(\mathrm{cm})$ & Numbers of seed/fruit \\
\hline \multirow{2}{*}{ 1st planting } & Shishi-homare & $8.9 \pm 5.1^{\mathrm{b}}$ & $1.6 \pm 0.4^{\mathrm{b}}$ & $6.8 \pm 2.2^{\mathrm{b}}$ & $51.8 \pm 33.1^{\mathrm{b}}$ \\
& $105 \mathrm{c}-10$ & $8.9 \pm 4.9^{\mathrm{b}}$ & $1.7 \pm 0.3^{\mathrm{b}}$ & $6.8 \pm 2.1^{\mathrm{b}}$ & $54.1 \pm 34.9^{\mathrm{b}}$ \\
\hline \multirow{5}{*}{ 2nd planting } & Shishi-homare & $4.3 \pm 1.6^{\mathrm{a}}$ & $1.2 \pm 0.2^{\mathrm{a}}$ & $5.0 \pm 1.1^{\mathrm{ab}}$ & $18.3 \pm 23.58^{\mathrm{a}}$ \\
& $105 \mathrm{c}-10$ & $4.5 \pm 1.2^{\mathrm{a}}$ & $1.3 \pm 0.2^{\mathrm{a}}$ & $5.2 \pm 1.5^{\mathrm{ab}}$ & $19.9 \pm 18.9^{\mathrm{a}}$ \\
& KounouShishito & $3.9 \pm 1.6^{\mathrm{a}}$ & $1.3 \pm 0.3^{\mathrm{a}}$ & $4.6 \pm 1.3^{\mathrm{a}}$ & $25.3 \pm 25.1^{\mathrm{a}}$ \\
& KairyoShishito & $4.4 \pm 2.1^{\mathrm{a}}$ & $1.3 \pm 0.3^{\mathrm{a}}$ & $4.9 \pm 1.9^{\mathrm{ab}}$ & $27.0 \pm 22.3^{\mathrm{a}}$ \\
\hline
\end{tabular}

a and bifferent letters within the same column indicate a significant difference at $5 \%$ level by Tukey's test.

The chili peppers grow best and are likely to reach the maximum yields at temperature from $21{ }^{\circ} \mathrm{C}$ to $33{ }^{\circ} \mathrm{C}$ [3]. After the 1 st flowering in the 2 nd planting, the temperature increases fluctuating from $37{ }^{\circ} \mathrm{C}$ to $42{ }^{\circ} \mathrm{C}$, and thereby affects the fruit weight. The fruit diameter and fruit length in the 2nd planting were smaller than these in the 1st planting. Among the varieties, fruits of "Kounou Shishito" are the smallest in shape. In 1982, Ali and Kelly [12] reported that fruit weigh, fruit length and fruit diameter of sweet pepper reduced in the high temperature conditions. In Shishito pepper, fruit weight reduced significantly and seeds per fruit was lowered under high temperature (38/30 ${ }^{\circ} \mathrm{C}$ day/night) [13].

The morphological characteristics of fruit were strongly affected under high temperature (Fig. 2). The highest fruit weight and fruit length were recorded on July 8 in harvested "Shishi-homare" fruits of the 1st 
planting (Fig. 2a). In both "Shishi-homare" and "105c-10" varieties in the 1st planting, fruit weight, fruit diameter and fruit length reduced rapidly after July 22, 2012, which correlates with the increase temperature at this time. The fruit weight reduced

$1^{\text {st }}$ planted fruit weight

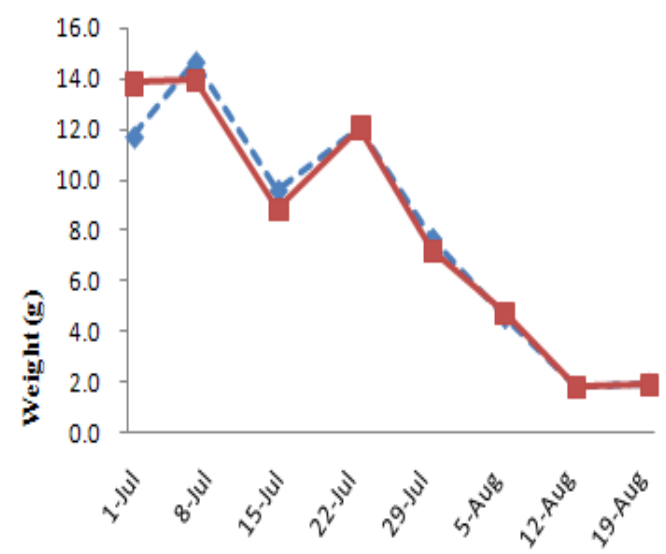

(a)

$1^{\text {st }}$ planted fruit diameter

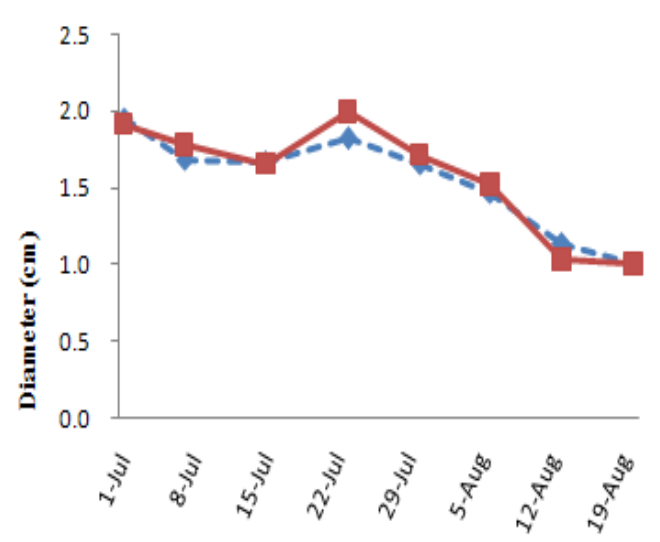

(c)

$1^{\text {st }}$ planted fruit length

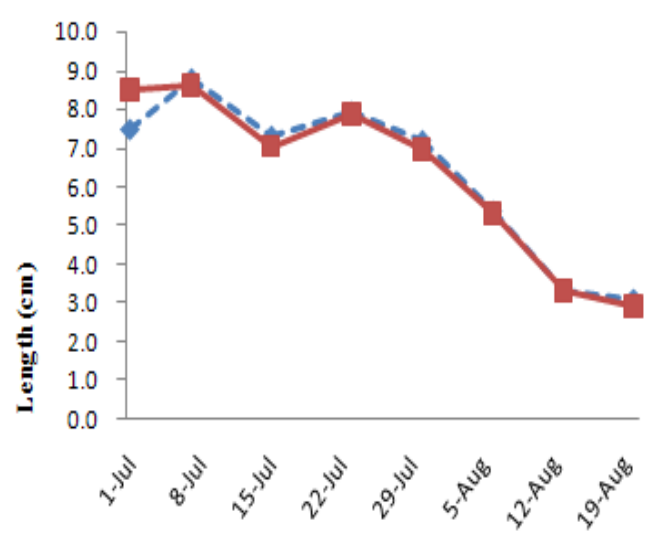

(e) strongly responding to high temperature in both "Shishi-homare" and "105c-10" varieties.

In the 2nd planting, the 1 st flower appeared when the temperature stayed in high condition $\left(37.8 / 24{ }^{\circ} \mathrm{C}\right.$, day/night), after that the temperature increased rapidly

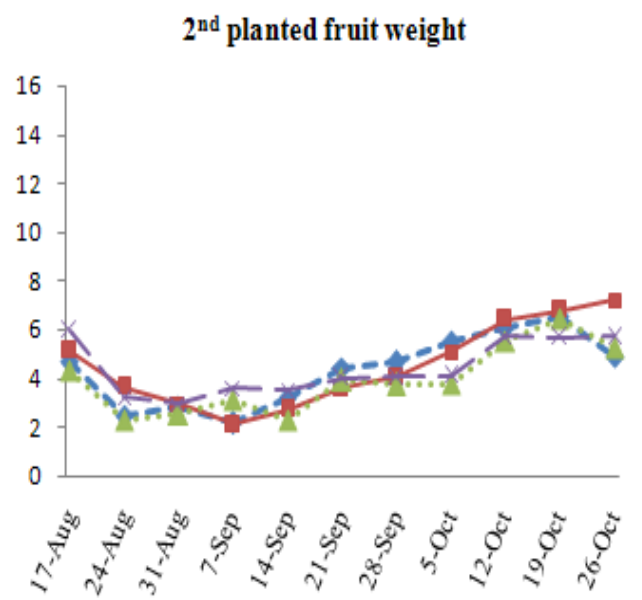

(b)

$2^{\text {nd }}$ planted fruit diameter

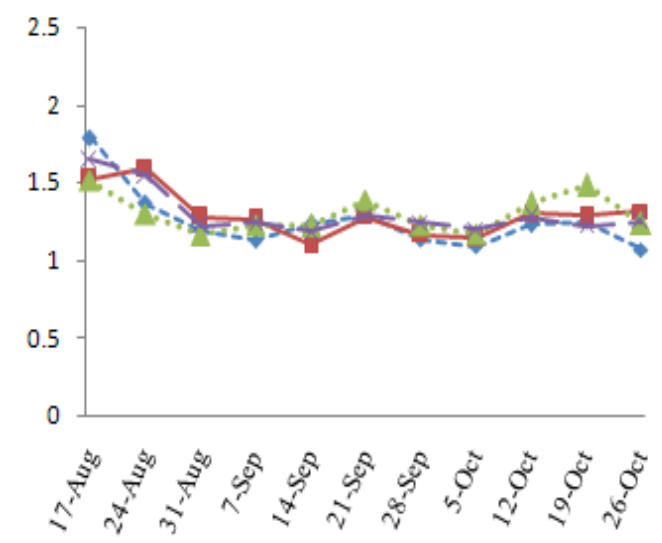

(d)

$2^{\text {nd }}$ planted fruit length

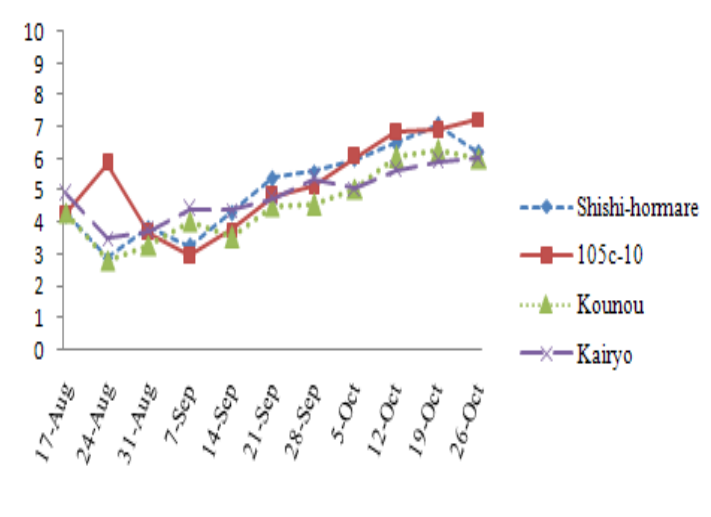

(f)

Fig. 2 The change of morphological fruit under two temperature regimes of two times of planting. 
and remained a long time. It correlates with the development of four morphological fruit varieties when the fruit weight, fruit diameter and fruit length were small in the 1 st harvested time and decreased gradually. After September 14th, fruit weight, fruit diameter and fruit length begun to increase, but it was still smaller than that in the 1st planting. The "Kounou Shishito" variety had the smallest fruit weight and fruit length (Fig. $2 \mathrm{~d}$ and $2 \mathrm{f}$ ) in almost harvested time.

During the 1 st flower appearing in the 2nd planting, the temperature condition fluctuated in $33-42^{\circ} \mathrm{C}$, thus the weight of fruit was effected. When the weight of fruit decreases, the diameter and the length of fruit will reduce, correlatively. The diameter and the length fruit in the 2nd planting were smaller than that in the 1 st planting. Thus, all of Shishito varieties in this experiment were impacted by high temperature.

In Japan, the annual temperature has been increasing at rate of $1.1^{\circ} \mathrm{C}$ per century since 1898 . As temperatures rise, the numbers of days with the minimum temperatures $\geq 25{ }^{\circ} \mathrm{C}$ and the maximum temperatures $\geq 35^{\circ} \mathrm{C}$ are increasing, respectively [14]. In plastic house, the temperature is higher than outside. High temperature $\left(\geq 35^{\circ} \mathrm{C}\right)$ has kept in long time since the early of June. The highest temperature in plastic house was $42.05{ }^{\circ} \mathrm{C}$, which was recorded by thermocouples. Shishito pepper grew best under the field and green house with temperature ranging from $21{ }^{\circ} \mathrm{C}$ to $33{ }^{\circ} \mathrm{C}[3,13]$. Field and controlled environment observations of pepper production indicate substantial abortion of floral buds occurs when day temperatures are $\geq 34{ }^{\circ} \mathrm{C}$ and/or night temperature are $\geq 21{ }^{\circ} \mathrm{C}$. Thus, when the maximum temperature per day was $\geq 34{ }^{\circ} \mathrm{C}$ during the day and night temperature $\geq 21{ }^{\circ} \mathrm{C}$ in early stage of July (Fig. 1a), the fruit weight, fruit diameter, fruit length and number seed of fruit decreased rapidly until the lst harvest of the 1 st planting and the almost harvest time of 2 nd planting. Fruit developed under over the suitable condition, therefore harvested fruits from the 2nd planting were smaller than that from the 1st planting (Fig. 2 and Table 2). Exposure to high temperature, from microspore mother cell meiosis of pepper flower to tetrad dissolution, in greatly reduces pollen viability and anther dehiscence [15]. High temperature inhibits the development of pollen grains during the period of final tetrad formation to tetrad dissolution. The reduction of pollen viability effectively reduces fruit size and fruit set [10]. After fertilization, the fruit size was determined by cell divisions and cell expansions. The Shishito pepper fruit width was the most sensitive to high temperature until 10 DAF and less effected from 30 DAF onwards [13]. Exposure to high temperature throughout fruit development significantly reduced Shishito pepper fruit weight. The reduction of fruit length and fruit diameter responds the reduction of fruit size in the high temperature condition in the 2 nd planting stage.

The reduction of seed numbers per fruit may have been partly responsible for the reduction of fruit size. A positive correlation was observed between fruit weight and number of seeds per fruit of sweet pepper $[10,16]$. In the 2nd planting, under the high temperature condition when the fruit weight decreased, the seeds/fruit reduces in the same way. Besides, under high temperature condition, the reduction in the number of viable pollen affect fertilization capacity, hence reducing number of seeds per fruits. After fertilization, abortion of seeds during the initial stages is probably due to failure in proper cell division, which might due to high temperature [13]. Thus, numbers of seed in all varieties reduced strongly in the 2 nd planting compared to the 1 st planting.

The results indicated that a significant response of Shishito pepper was observed under high temperature condition in the summer. Fruit quality of Shishito was reduced drastically. Thus, managing the time to sowing and harvesting is necessary for growing chilli pepper. 


\section{Conclusions}

The morphological fruits (the fruit weight, the fruit diameter, the fruit length and number of seeds per fruit) under high temperature decreased strongly. The results indicated a significant difference in the response of Shishito when the temperature increased in the summer. Fruit quality of Shishito reduced clearly in bad condition for growing. Thus, managing the time to sowing and harvesting is so necessary when growing sweet pepper.

\section{Reference}

[1] Ishikawa, K., Sasaki, S., Matsufuji, H., and Nunomura, O. 2004. "High $\beta$-Carotene and Capsaicinoid Contents in Seedless Fruits of 'Shishitoh' Pepper." HortScience 39 (1): 153-5.

[2] The Japanese Society for Horticultural Science. 2006. Horticulture in Japan. Japan: Shoukadoh Publishing of Nakanishi Printing Co., Ltd..

[3] Pagamas, P., and Nawata, E. 2007. "Effect of High Temperature during Seed Development on Quality and Chemical Composition of Chili Pepper Seeds.” Jp. J. Trop. Agr. 51 (1): 22-9.

[4] Mansour-Gueddes, S. B., Tarchoun, N., Teixeira da Silva, J. A., and Saguem, S. 2010. "Agronomic and Chemical Evaluation of Seven Hot Pepper (Capsicum annum L.) Populations Grown in an Open Field.” Fruit, Vegetable and Cereal Science and Biotechnology 4 (1): 93-7.

[5] Polowick, P. L., and Sawhney, V. K. 1985. "Temperature Effects on Male Fertility and Flower and Fruit Development in Capsicum annuum L.." Scientia Horticulture 25 (2): 117-27.

[6] Saha, S. R., Hossain M. M., Rahman M. M., Kuo, C. G., and Abdullah, S. 2010. "Effect of High Temperature Stress on the Performance of Twelve Sweet Pepper
Genotypes.” Bangladesh J. Agril. Res. 35 (3): 525-34.

[7] Khanduri, V. P., Shamar, C. M., and Singh, S. P. 2008. "The Effect of Climate Change on Plant Phenology." Environmentalist 28 (2): 143-7.

[8] Inthichack, P., Nishimura, Y., and Fukumoto, Y. 2013. "Diurnal Temperature Alternations on Plant Growth and Mineral Absorption in Eggplant, Sweet Pepper and Tomato." Hort. Envir. Biotechnol. 54 (1): 37-43.

[9] Cross, R. H., Mckay, S. A. B., Mchughen, A. G., and Bonham-Smith, P. C. 2003. "Heat Stress Effects on Reproduction and Seed Set in Linum usitatissimum L. (Flax)." Plant Cell Envir. 26 (7): 1013-20.

[10] Erickson, A. N., and Markhart, A. H. 2001. "Flower Production, Fruit Set and Physiology of Bell Pepper during Elevated Temperature and Vapor Pressure Deficit." J. Amer. Soc. Hort. Sci. 126 (6): 697-702.

[11] Qumer, I., Muhamad, A., Muhamad, R. A., Muhamad, A. A., and Riaz, A. 2009. "Vegetative and Reproductive Evaluation of Hot Peppers under Different Plastic Mulches in Ploy/Plastic Tunnel.” Pak. J. Agri. Sci. 46 (2): 113-8.

[12] Ali, A. M., and Kelly, W. C. 1993. "Effect of Pre-anthesis Temperature on the Size and the Shape of Sweet Pepper (Capsicum spp. L.) Fruit." Scientia Horticulturae 54: 97-105.

[13] Pagamas, P., and Nawata, E. 2008. "Sensitive Stages of Fruit and Seed Development of Chili Pepper (Capsicum annuum L. var. Shishito) Expose to High Temperature Stress." Scientia Horticulturae 117 (1): 21-5.

[14] MEXT, JMA and MOE. 2009. Climate Change and Its Impact in Japan. Synthesis Report on Observations, Projections and Impact Assessments of Climate Change.

[15] Erickson, A. N., and Markhart, A. H. 2002. "Flower Development Stage and Organ Sensitivity of Bell Pepper (Capsicum annuum L.) to Evaluated Temperature." Plant, Cell and Environment 25: 123-30.

[16] Heuvelink. E., and Korner, O. 2001. "Parthenocarpic Fruit Growth Reduces Yield Fluctuation and Blossom-End Rot in Sweet Pepper.” Ann. Bot. 88: 69-74. 